\title{
Limited coupling of macrophyte production and bacterial carbon cycling in the sediments of Zostera spp. meadows
}

\author{
H. T. S. Boschker ${ }^{1, *}$, A. Wielemaker ${ }^{1}$, B. E. M. Schaub ${ }^{1}$, M. Holmer ${ }^{2}$ \\ ${ }^{1}$ Centre for Estuarine and Coastal Ecology, Netherlands Institute of Ecology, Postbus 140, 4400 AC Yerseke, The Netherlands \\ ${ }^{2}$ Institute of Biology, Odense University, Campusvej 55, 5230 Odense M, Denmark
}

\begin{abstract}
Two approaches were used to study coupling between seagrass production and bacterial processes in the rhizosphere. In the first approach, stable carbon-isotope ratios of bacteria, sediment organic matter and plants were determined to infer sources of organic carbon used by bacteria in the sediments of 4 European Zostera marina and $2 Z$. noltii meadows. Bacterial isotope ratios were derived from bacteria-specific polar lipid-derived fatty acids (PLFA), mainly methyl-branched i15:0 and a15:0. Bacterial $\delta^{13} \mathrm{C}$ ratios in the sediment from both vegetated and unvegetated sites were mostly similar and did not resemble $Z$. marina ratios, suggesting that seagrass material was of limited importance as a bacterial carbon source. Bacterial ratios were in most cases similar to benthic macroalgae and did correlate well with ratios of diatom biomarkers. Sediment organic matter inside the meadows had $\delta^{13} \mathrm{C}$ ratios similar to those of nearby unvegetated sites, and ratios were clearly different from the material produced by seagrasses, indicating that little seagrass material accumulated. Results from the $2 \mathrm{Z}$. noltii sites were less conclusive, as there was no clear difference in $\delta^{13} \mathrm{C}$ ratios between the potential source materials. In addition, bacterial $\delta^{13} \mathrm{C}$ ratios were highly variable at one $Z$. noltii site. In the second approach, cultured $Z$. marina was labeled with ${ }^{13} \mathrm{C}$-bicarbonate to study the short-term transfer of label from plants to bacteria in the rhizosphere. However, no label was detected in bacterial PLFA after $20 \mathrm{~h}$ of incubation. In conclusion, a close coupling between macrophyte production and bacterial carbon cycling could not be detected in the sediment of $Z$. marina meadows, and benthic production by algae was probably the main carbon source for bacterial growth.
\end{abstract}

KEY WORDS: Seagrass meadows - Bacterial carbon sources $\cdot$ Sediment $\cdot$ Stable carbon isotopes · Biomarkers $\cdot$ Zostera marina $\cdot$ Zostera noltii

Resale or republication not permitted without written consent of the publisher

\section{INTRODUCTION}

Seagrass meadows are an important component of many temperate coastal zones. They are productive ecosystems (Duarte \& Chiscano 1999) and, as grazing by herbivores is generally low, much of this production will eventually enter the detritus food chain (Mann 1988, and references therein). Bacterial activities are high in the sediments of seagrass beds, which is gener-

*E-mail: boschker@cemo.nioo.knaw.nl ally thought to be the result of seagrass detritus inputs (Pollard \& Moriarty 1991, Holmer \& Nielsen 1997). In addition, living seagrass roots may excrete organic compounds that stimulate bacterial mineralization processes in the rhizosphere (Wetzel \& Penhale 1979, Moriarty et al. 1986). Reduction of water-flow rates enhances sedimentation and decrease sediment erosion in seagrass beds (Gambi et al. 1990, Worcester 1995), which will also stimulate sedimentary carbon cycling by increasing organic matter inputs. As a result, bacterial activities are generally higher in vegetated sediments than in nearby unvegetated sites (Pol- 
lard \& Moriarty 1991, Isaksen \& Finster 1996) and are positively related to plant shoot densities (Holmer \& Nielsen 1997) and productivity (López et al. 1995). Also, diurnal variation in bacterial activities has been found in seagrass sediments, with higher activities during the daytime and lower activities during the night (Oremland \& Taylor 1977, Moriarty \& Pollard 1982, Welsh et al. 1997, Blaabjerg et al. 1998). These data indicate that a fast and close coupling may exist between seagrasses and bacteria, and therefore suggest that seagrass material is an important carbon source for bacterial growth in the rhizosphere of seagrasses.

Stable carbon-isotope compositions are widely used to study the sources of organic carbon in ecosystems and their use in the food web (Fry \& Sherr 1984). Seagrasses show a rather broad range in stable carbonisotope ratios between -23 and $-3 \%$ o $\left(\delta^{13} \mathrm{C}\right.$-notation); however most ratios vary around $-10 \%$ (McMillan et al. 1980, Hemminga \& Mateo 1996). These relatively positive $\delta^{13} \mathrm{C}$ ratios compared to other potential source materials make it possible to trace seagrass material in ecosystems (e.g. Thayer et al. 1978). We recently developed a method to study carbon sources used by bacteria that is based on the analysis of isotopic ratios of bacterial biomarkers (Boschker et al. 1999). The specific bacterial biomarkers used in this method are branched polar lipid-derived fatty acids (PLFA), mainly i15:0 and a15:0. PLFA are widely used to study microbial biomass and community structure in sediments (Parkes 1987, Tunlid \& White 1992). Stable isotope ratios of individual PLFA can be determined by gas chromatography coupled to isotope-ratio mass spectrometry (Hayes et al. 1990, Boschker et al. 1999). If seagrass material is an important carbon source for bacterial processes in sediment, the isotopic composition of the bacterial PLFA should reflect the seagrass $\delta^{13} \mathrm{C}$ ratios (Boschker et al. 1999).

We have studied stable carbon-isotope ratios of carbon used by bacteria in the sediments of several northwest European Zostera spp. beds, to determine if seagrass material was indeed the dominant carbon source. Beds with the 2 dominant northwest European species, $Z$. marina and $Z$. noltii, were sampled. In an additional study, we performed a labeling experiment in which cultured Z. marina was incubated with ${ }^{13} \mathrm{C}$-bicarbonate and short-term label transfer between plants and bacterial biomarkers in the sediment was determined.

\section{MATERIAL AND METHODS}

Field sites and sampling. Four Zostera marina meadows were sampled in different parts of northwestern Europe (see Table 1 for additional information): peren- nial seagrass meadows with an organic-poor (D1) and organic-rich sediment (D2) at micro-tidal Slipshavn, Nyborg Fjord, Danish Baltic, in July 1998; an annual stand in a large creek (N1) at the macro-tidal Sint Annaland salt marsh, Eastern Scheld, The Netherlands, in August 1998; and a macro-tidal, perennial meadow (F1) near the harbor of Arcachon, Arcachon Bay, France, in July 1998 (Castel et al. 1996). In addition, 2 large $Z$. noltii vegetations were sampled in Arcachon Bay at sites with organic-poor (FA) and organic-rich sediments (FB). This selection of seagrass meadows represents a wide range of typical systems, a range of sediment types, and the 2 main seagrass species in northwestern Europe.

Triplicate sediment cores were taken from both vegetated sites and nearby unvegetated sites. The top $5 \mathrm{~cm}$ of the sediment containing most of the Zostera spp. roots was mixed and used for PLFA and organic matter analyses. All sediments were anoxic below the first few millimeters. Samples of shoots and roots from Zostera spp. and of benthic macro-algae were also collected. Sediment and plant material were frozen on the day of sampling and subsequently freeze-dried. Cores for sulfate-reduction rate measurements were also taken at the sites in Denmark and The Netherlands. Silt content $(<63 \mu \mathrm{m})$ of the sediments was measured with a Malvern Particle Sizer 3600 E.

Labeling experiment. To study the short-term transfer of organic matter between plants and bacteria, Zostera marina was grown in a mesocosm and labeled with ${ }^{13} \mathrm{C}$-bicarbonate, after which the label distribution in plants, sediment and bacterial biomarkers was measured. Square plastic containers $(9.5 \times 9.5 \times 11 \mathrm{~cm} \mathrm{[1 \times}$ $\mathrm{w} \times \mathrm{h}])$ were filled with sieved $(1 \mathrm{~mm})$ and washed fine-grained sand and silt collected at the Zandkreek, Eastern Scheld, southwestern part of The Netherlands. Containers were planted with shoots of $Z$. marina collected at the same site. Containers were placed in an aquarium filled with diluted seawater (salinity 23\%), which was replaced every week. Plants were grown for $5 \mathrm{mo}$ at $18^{\circ} \mathrm{C}$ and $200 \mu \mathrm{E} \mathrm{m} \mathrm{m}^{-2} \mathrm{~s}^{-1}$ until they reached an above- and belowground biomass of $85 \pm 31$ and $43 \pm 27 \mathrm{~g}$ dry $\mathrm{wt} \mathrm{m}^{-2}$, respectively, and a shoot density of $1660 \pm 440 \mathrm{~m}^{-2}$. These biomass and shoot-density data are at the high end of the range as found for $Z$. marina meadows in the southwestern part of The Netherlands (van Lent \& Verschuure 1994).

For the labeling experiment, individual containers were placed in transparent plastic bags filled with $4 \mathrm{l}$ diluted seawater. Label (2 ml, 0.8 $\mathrm{M} \mathrm{Na}_{2} \mathrm{H}^{13} \mathrm{CO}_{3}[99 \%$ ${ }^{13} \mathrm{C}$, ISOTEC]) was added, which resulted in a $16 \%{ }^{13} \mathrm{C}$ labeling of the bicarbonate pool. After $4 \mathrm{~h}$, the labeled water was removed and containers were placed in unlabeled seawater for $16 \mathrm{~h}$ to allow label to distribute in the plants. To avoid labeling of benthic micro-algae, 


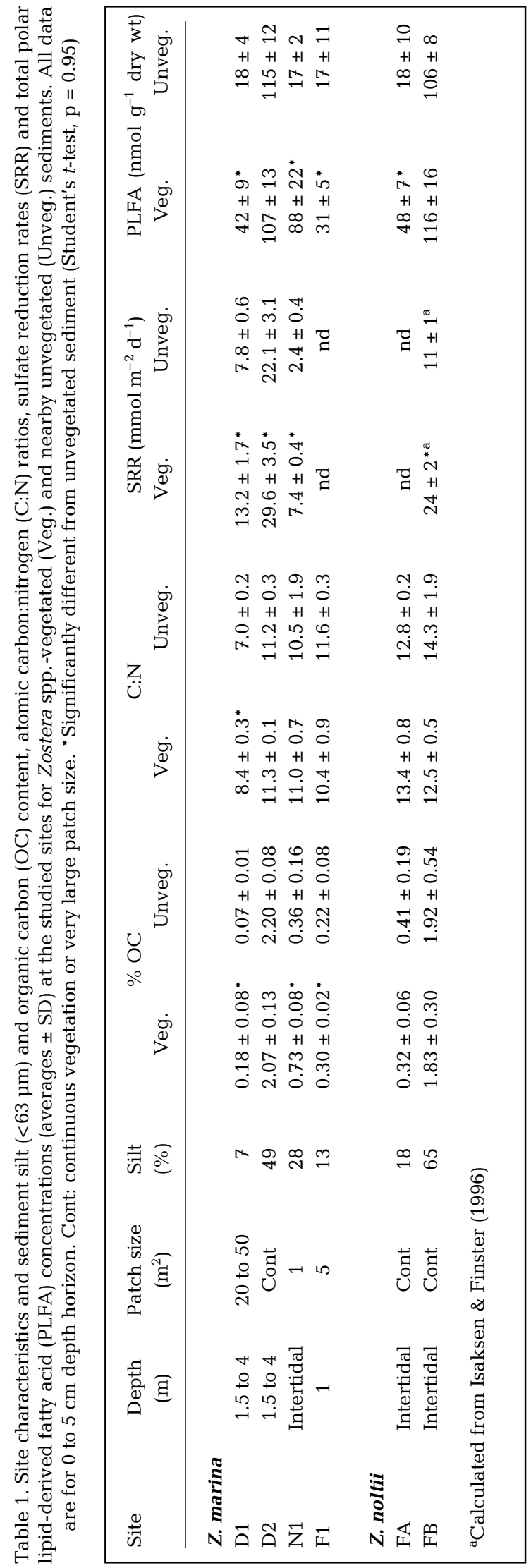

the top half-centimeter of the sediment was replaced with washed sediment $1 \mathrm{wk}$ before the start of the labeling. In addition, the sediment was covered with an approximately $0.5 \mathrm{~cm}$ thick layer of black agar $(3 \%$ agar [Difco] and $2.5 \%$ carbon powder [Merck] in diluted seawater [salinity $23 \%$ ]) shortly before the experiment. This completely blocked light from reaching the sediment surface and the benthic micro-algae. Unlabeled containers with and without vegetation, and labeled dark control incubations with Zostera marina were also studied.

After the $20 \mathrm{~h}$ incubation, shoots were removed and 3 small sediment cores (i.d. $1.75 \mathrm{~cm}$ ) were taken and pooled for PLFA and sediment analyses. The remaining sediment was sieved $(0.47 \mathrm{~mm})$ and roots and rhizomes were collected. Plant material and sediments were freeze-dried and ground to a fine powder before analysis.

Characterization of plant and sediment organic matter. Carbon and nitrogen contents of plants and sediments were determined using a Carlo-Erba NA $1500 \mathrm{CN}$ analyzer following an in situ $\mathrm{HCl}$ acidification procedure (Nieuwenhuize et al. 1994). Carbon isotopes were measured on a Fisons NA1500 elemental analyzer coupled on-line (via a continuous flow interface) to a Finnigan Delta S isotope-ratio mass spectrometer. All stable carbon-isotope data are reported in the $\delta$ notation relative to Vienna-PDB.

PLFA extraction and analysis. Lipids were extracted with a modified Bligh and Dyer extraction using $50 \mathrm{ml}$ screw-cap centrifuge tubes (Findlay et al. 1989). The total lipid extract was fractionated on silicic acid (Merck) into different polarity classes by sequential eluting with chloroform, acetone and methanol. PLFA in the methanol fraction were derivatized using mild alkaline methanolysis to yield fatty acid methyl esters (FAME) (Guckert et al. 1985). Concentrations of FAME were determined by gas chromatography-flame ionization detection. Isotopic composition of individual FAME was determined with a Varian 3400 gas chromatograph equipped with a Varian SPI injector, which was coupled via a Type II combustion interface to a Finnigan Delta $\mathrm{S}$ isotope-ratio mass spectrometer. A detailed description of the methods is given in Boschker et al. (1999).

Stable isotopic composition of bacteria was calculated from the isotope data of bacterial FAME in several steps. Carbon-isotope ratios of FAME were corrected for the 1 carbon atom in the methyl group added during derivatisation to obtain the actual PLFA ratio (Rieley 1994, Boschker et al. 1999). The dominant bacterial markers (i15:0 and a15:0) were not separated under the chromatographic conditions used (about $10 \%$ peak overlap) and results of these PLFA were therefore combined by using an isotope balance 
(Boschker et al. 1999). As shown by Boschker et al. (1999), the bacterial PLFA i+a15:0 are depleted in ${ }^{13} \mathrm{C}$ by $-5.6 \pm 1.8 \%$ compared to the bacterial substrate. The isotopic composition of the bacteria biomass was therefore calculated from the PLFA ratio as: $\delta^{13} \mathrm{C}_{\text {bact }}=$ $\delta^{13} \mathrm{C}_{\mathrm{i}+\mathrm{a} 15: 0}+5.6(\%)$.

Sulfate reduction rates. Sulfate reduction rates (SRR) were measured by the core-injection technique using ${ }^{35} \mathrm{~S}_{-} \mathrm{SO}_{4}{ }^{2-}$ (Jørgensen 1978). Sediments were incubated for $4 \mathrm{~h}$ at in situ temperature and fixed with $10 \% \mathrm{ZnSO}_{4}$ (sediment: $\mathrm{ZnSO}_{4}$ volume ratio = 2:1). Reduced sulfur compounds were distilled from the sediment according to the single-step procedure described by Fossing \& Jørgensen (1989). Sulfate concentrations in the porewater samples were analyzed by ion-chromatography with a Dionex auto-suppressed anion system (IonPac AS11 column with ASRS suppressor).

Statistics. The Student's $t$-test was used throughout the study to test for differences $(p=0.95)$.

\section{RESULTS}

\section{Field study}

Stable isotope ratios of Zostera spp. ranged from -7 to $-15 \%$, with no consistent differences between shoot and root/rhizome material (Figs. 1 \& 2). If present, benthic macro-algae $(-13$ to $-18 \%$ o) were somewhat depleted in ${ }^{13} \mathrm{C}$ compared to seagrass material. Sediment organic carbon (OC) was clearly depleted in ${ }^{13} \mathrm{C}$ compared to seagrasses and macro-algae at all sites, and ranged between -16 and $-25 \%$. At the $Z$. noltii Site FA, vegetated sediment had a somewhat enriched isotope signal compared to the unvegetated sediment, and was therefore shifted in the direction of seagrass material. All other sites, however, showed no significant effect of vegetation on sediment isotope ratios.

At the Zostera marina sites, bacterial isotope ratios, derived from the specific bacterial PLFA i+a15:0, fell in all cases between the seagrass and sediment ratios (Fig. 1). For most sites, bacterial ratios from vegetated and unvegetated sites were not significantly different, suggesting that bacteria grew on a similar source of OC. At Site N1 only, bacteria from vegetated sediment were enriched in ${ }^{13} \mathrm{C}$ compared to the unvegetated sediment and were therefore shifted in the direction of the seagrass material. For both $Z$. marina and $Z$. noltii sites, bacterial isotope ratios in the sediment were in the range found for benthic macro-algae. Furthermore, ${ }^{13} \mathrm{C}$ val- ues for bacterial PLFA (i+a15:0) were highly correlated to the 20:503 PLFA (Fig. 3), which is a major component of micro-algae such as benthic diatoms (Ratledge $\&$ Wilkinson 1989). Two samples from the unvegetated sediment at Site FA did not follow the relation between bacterial and algal PLFA, and were treated as outliers although we do not know why they behaved differently. The points with the most depleted isotope ratios (Fig. 3) are from the Dutch site (N1). As described above, bacterial isotope ratios from the vegetated Site N1 were somewhat enriched compared to the unvegetated control site, which could indicate a limited use of Zostera spp. material (see also Fig. 1).

Isotopic compositions at the Zostera noltii sites were unfortunately less revealing than at the $Z$. marina sites for various reasons (Fig. 2). At Site FB, there was no large difference between ${ }^{13} \mathrm{C}$ ratios of seagrasses and benthic macro-algae, which made it difficult to distinguish these 2 potentially important sources for bacterial growth. At Site FA, a comparison between the vegetated and unvegetated sediments was difficult as the bacterial ratios were highly variable for the unvegetated sediment, with 2 samples at about $-19 \%$ o (the 2 outliers in Fig. 2) and 1 at $-12 \%$.

Sediment characteristics and microbial parameters at the different sites are presented in Table 1. The OC content of the Zostera marina sediments was up to 2

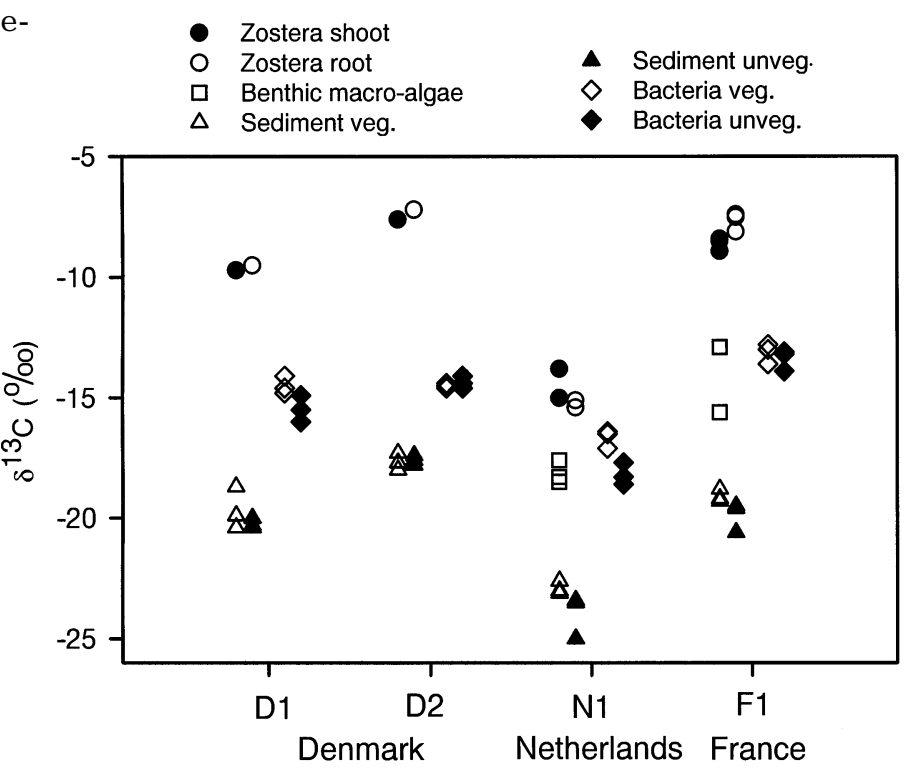

Fig. 1. Results of field study on carbon sources used by bacteria in Zostera marina seagrass meadows in northwestern Europe. Shown are stable carbon isotope ratios of plants, benthic macro-algae, sediment organic matter and bacteria for both vegetated (veg.) and nearby unvegetated (unveg.) sites. At Site N1, macro-algae (Ulva spp; Enteromorpha spp. and an unidentified filamentous green algae) showed similar isotopic ratios. At Site F1, macro-algae Monostroma spp. were clearly enriched in ${ }^{13} \mathrm{C}$ compared to an unidentified filamentous red algae 
times higher than the unvegetated control sediments, with the exception of the Danish site with the high organic matter content (D2), where contents were similar. The $Z$. noltii sites showed no significant differences in sediment organic matter content. C:N ratios were low, ranging from 7 to 11 for the $Z$. marina sites

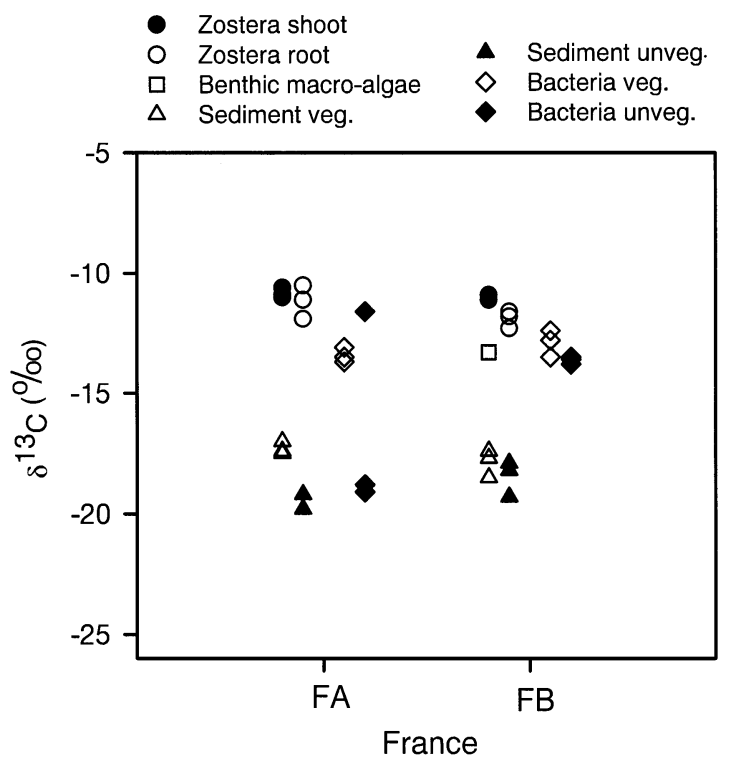

Fig. 2. Results of field study on carbon sources used by bacteria in Zostera noltii seagrass meadows in Bay of Arcachon, France. Shown are stable carbon isotope ratios of plants, benthic macro-algae Monostroma spp., sediment organic matter and bacteria for both vegetated and nearby unvegetated sites

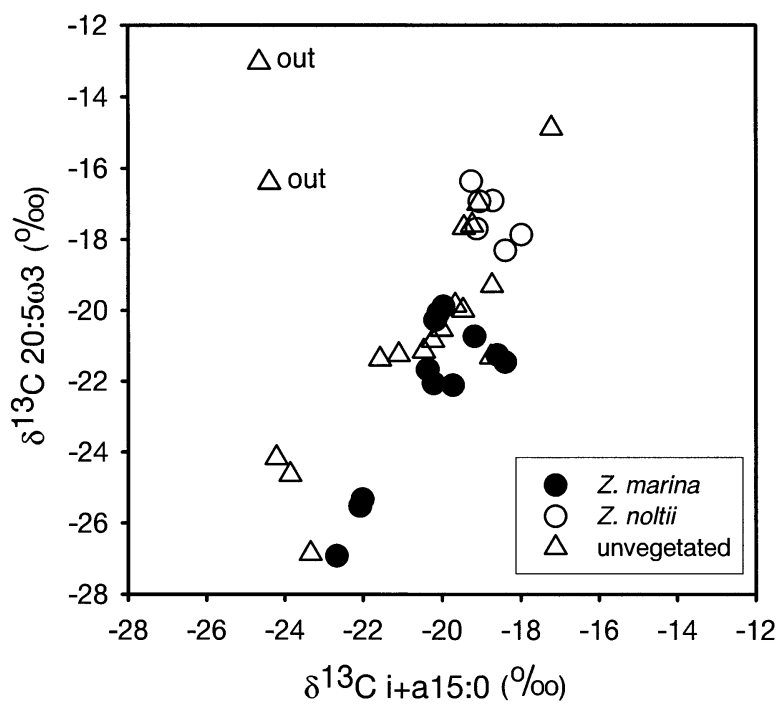

Fig. 3. Relationship between stable carbon-isotope ratios of bacterial (i+a15:0) and dominant algal (20:5 03$)$ polar lipidderived fatty acids in the sediment of all (Zostera spp.-vegetated and unvegetated) sites. Two outliers from unvegetated Site FA are labeled 'out'. Data are significantly correlated when the 2 outliers are excluded $\left(\mathrm{r}^{2}=0.67, \mathrm{n}=34\right)$ and around 13 for the $Z$. noltii sediments. Vegetated and unvegetated locations showed no significant difference in C:N ratios, with the exception of Site D1, where the $C: N$ ratio was higher at the vegetated site. SRR were about 2 times higher for the vegetated sediments. Total PLFA concentrations, indicating total biomass, were mostly substantially higher at the vegetated sites, with the exception of the sediments at Sites D2 and FB, which also had the highest PLFA concentrations.

\section{Labeling experiment}

After incubation in the light with ${ }^{13} \mathrm{C}$-bicarbonate, both Zostera marina shoots and roots/rhizomes were highly labeled (Table 2). Plants incubated in the dark incorporated only small amounts of label. A small increase in the $\delta^{13} \mathrm{C}$ ratio was found in the sediment organic matter of the light incubations, which may have been caused by the presence of highly labeled root material in the samples or by exudation by roots (Table 2). PLFA that are also found in Zostera spp. $(16: 0,18: 0,18: 1,18: 2$ and 18:3; Canuel et al. 1997) were labeled after incubation with ${ }^{13} \mathrm{C}$-bicarbonate (data not shown), which is most likely the direct result of the highly labeled root material in the samples. However, no label was detected in bacteria based on the bacterial marker PLFA i+a15:0 (Table 2). This showed that there was no short-term transfer between plants and bacteria. Other bacterial PLFA (i14:0 and i16:0) and compounds generally not found in macrophytes $(15: 0,16: 1$ and 17:0) also gained no significant amounts of label (data not shown).

Stable isotope ratios in control incubations to which no label was added showed similar trends to the field study. Bacterial ratios were also clearly depleted compared to plants, and were not affected by the presence of plants (Table 2). Sediment OC in incubations with and without plants had similar ${ }^{13} \mathrm{C}$ ratios and was depleted by about $10 \%$ compared to Zostera marina (Table 2).

\section{DISCUSSION}

The results of both the field study and labeling experiment with Zostera marina suggest that coupling between seagrass productivity and bacterial growth was of limited importance. Natural isotope ratios of bacteria were not similar to seagrass material, but fell between those of $Z$. marina plants and sediment organic matter, which may suggest that bacteria were using a mixture of these 2 materials. However, bacterial isotope data from the vegetated and nearby unveg- 
Table 2. Zostera marina. Results of labeling experiment. Bacteria data based on stable isotope ratios of the i+a15:0 bacterial PLFA. * Significantly different from start containers (Student's $t$-test, $\mathrm{p}=0.95$ )

\begin{tabular}{|c|c|c|c|c|}
\hline \multirow[t]{2}{*}{ Treatment } & \multicolumn{4}{|c|}{$\delta^{13} \mathrm{C}(\%)$ average $\pm \mathrm{SD}$} \\
\hline & Shoot & Root/rhizome & Sediment & Bacteria \\
\hline No plant & - & - & $-20.9 \pm 0.7$ & $-17.7 \pm 0.2$ \\
\hline Start & $-8.9 \pm 0.3$ & $-10.2 \pm 0.5$ & $-20.4 \pm 0.3$ & $-17.7 \pm 0.4$ \\
\hline End, dark & $-7.0 \pm 0.2^{*}$ & $-9.0 \pm 0.1^{*}$ & $-20.8 \pm 0.2$ & $-17.5 \pm 0.4$ \\
\hline End, light & $476 \pm 53^{*}$ & $131 \pm 71^{*}$ & $-17.8 \pm 0.5^{*}$ & $-17.6 \pm 0.4$ \\
\hline
\end{tabular}

etated sites and incubations were mostly very similar, which indicates that the source of the bacterial substrate was not affected by the presence of seagrasses. Only at the Dutch Z. marina site (N1) did bacteria show a more enriched signal, which may suggest a contribution by seagrass material. A likely candidate for the main bacterial substrate was material derived from benthic algae, as isotopic ratios of benthic macro-algae fell in the same range as the bacteria for the field study (Fig. 1) and isotope ratios of benthic micro-algae and bacterial biomarkers were highly correlated (Fig. 3). Material derived from seagrass epiphytes may also have contributed to the bacterial substrate, although no samples were taken. A vastly lower growth efficiency for bacteria growing on seagrass material compared to algal material is not a likely explanation for our results, as del Giorgio \& Cole (1998) reported a similar range of growth efficiencies for macrophyte and algal material and Coffin et al. (1997) showed that sedimentary bacterial $\delta^{13} \mathrm{C}$ ratios respond within a day to the addition of seagrass material. Results of the $Z$. noltii field study were less revealing, as stable isotope ratios of primary producers were similar or bacterial isotope data were highly variable (Fig. 2).

Microbial biomass and activities in the sediments of seagrass beds are in many cases higher than at nearby unvegetated sites (Pollard \& Moriarty 1991, López et al. 1995, Isaksen \& Finster 1996, Holmer \& Nielsen 1997, this study). Our results, however, suggest that this stimulation was not due to the input of seagrass material into the sediment and the use of this material by bacteria. Alternatively, seagrasses can also indirectly influence carbon cycling in the sediment by decreasing water flows over the sediment (Gambi et al. 1990, Worcester 1995). This canopy friction enhances sedimentation and reduces resuspension of the sediment, and will thereby increase the availability of OC to the bacterial community in the sediment. In addition, conditions inside seagrass beds may be more favorable for benthic algae due to the reduced losses by resuspension. These secondary effects of seagrasses on carbon cycling therefore most probably dominated in the Zostera marina sediments studied.
The isotopic composition of the sediment organic matter at the field sites showed that Zostera marina-derived material did not accumulate in the sediment to any major extent, although organic matter concentrations were mostly higher for vegetated sites. This discrepancy between $\delta^{13} \mathrm{C}$ ratios of seagrasses and sediment organic matter has been found in many other studies (Simenstad \& Wissmar 1985, Cooper 1989, Dauby 1989 , Hemminga et al. 1994, Fourqurean et al. 1997). Sediment ratios were around $-20 \%$, which is typical for phytoplankton or suspended OC in the studied systems (e.g. Salomons \& Mook 1981, Richard et al. 1997, Voss \& Struck 1997). The low C:N ratios of the sediment organic matter (Table 1) also point towards a predominant algal source.

In agreement with the field study, a close coupling between plants and rhizosphere bacteria was also not detected in the labeling experiment, as we did not find any short-term transfer between Zostera marina and bacterial biomarkers. It may be argued that the incubation time of $20 \mathrm{~h}$ used in this experiment was too short for the label to be transported from the shoots to the bacteria in the sediment. However, roots (Table 2) and root-derived PLFA were highly labeled in our experiment. Furthermore, several studies have shown that microbial activities such as bacterial secondary productivity (Moriarty \& Pollard 1982), sulfate reduction rates (Pollard \& Moriarty 1991, Blaabjerg et al. 1998), and nitrogen fixation (Welsh et al. 1997) are significantly higher during the day than during the night, which is mostly explained by assuming that bacterial processes in the seagrass rhizosphere depend to some extent on a fast transport of recently fixed OC. Moreover, in a tropical seagrass meadow, $11 \%$ of the ${ }^{14} \mathrm{C}$ label fixed by the seagrasses was detected in the sediment and used by bacteria after only $6 \mathrm{~h}$ of incubation (Moriarty et al. 1986), suggesting that in some cases label transfer is fast, possibly in the form of readily available root exudates. Based on these literature data, a substantial labeling of the rhizosphere bacteria was anticipated during our short labeling experiment which was, however, not detected. Furthermore, in another labeling study, Middelburg et al. (2000) showed that coupling between benthic micro-algae and bacteria is fast, with detectable transfer of label within $4 \mathrm{~h}$ and maximum labeling of the bacteria after 1 to $2 \mathrm{~d}$.

It is, however, possible that some of the observations in the literature on day-night shifts in bacterial activities also result from secondary effects. For instance, the higher bacterial productivity in the light (Moriarty \& Pollard 1982) could be caused by a shift to more oxic 
types of bacterial respiration because of oxygen leakage from the seagrass roots. Oxygen is mainly released from the seagrass roots during the day when plants are photosynthesizing (Smith et al. 1984, Caffrey \& Kemp 1991), or oxygen release is much lower during the night than during the day (Pedersen et al. 1998). Aerobic bacteria mostly have higher growth yields than anaerobic bacteria, and furthermore are more widely able to incorporate the thymidine label (Gilmour et al. 1990, Wellsbury et al. 1994) that was used in this study (Moriarty \& Pollard 1982). The diurnal variation in sulfate reduction rates (Pollard \& Moriarty 1991, Blaabjerg et al. 1998) and in the nitrogen fixation by sulfate reducers (Welsh et al. 1997) is more difficult to explain as secondary effects caused by root oxygen release, as this probably would have had the opposite effect by decreasing sulfate reduction rates during the day. The short-term transfer of ${ }^{14} \mathrm{C}$ label may have been overestimated by Moriarty et al. (1986), as it can be difficult to physically separate the highly labeled plant material completely from the sediment matrix (Swinnen et al. 1994). Another possible explanation for their fast transfer is that benthic micro-algae were present on the sediment and that incorporation of label by these phototrophic organisms was mistaken for uptake by bacteria. Benthic micro-algae are a common component of seagrass beds (e.g. Murray \& Wetzel 1987, Moncreiff et al. 1992, this study). Our technique is, however, based on the use of specific bacterial biomarkers, which makes the absolute separation of plant, microalgal and bacterial material possible.

It is also possible that the relatively minor importance of seagrass material for bacterial growth in our study was a result of site selection. In a recent study on salt-marsh sediments, Boschker et al. (1999), using the same technique, showed that the contribution of local plant material to bacterial growth is highly variable between sites. The main factor influencing this contribution is the input of other materials to the sediment by sedimentation relative to local plant inputs. The input of macrophyte material into the sediment also varied between salt-marsh plant species. Despite the range of systems studied, little of the variation found for salt marshes was detected in the present study on typical northwest European Zostera marina meadows. As seagrasses show a considerable variation in growth strategy (den Hartog 1977), it may be expected that plantbacteria coupling depends to some extent on the seagrass species studied (Wetzel \& Penhale 1979). In addition, at oligotrophic sites with very little input of organic matter from other sources, local seagrass production may be relatively more important than at the sites studied in this paper. Especially tropical seagrass meadows associated with coral reefs are interesting objects for a comparative study, since these systems often have a high standing biomass of different seagrass species and their sediments are mostly very poor in organic matter (e.g. Hemminga et al. 1994, Miyajima et al. 1998).

In conclusion, our stable carbon-isotope study suggests that carbon fixed by seagrasses does not enter the sediment to a major extent in Zostera marina meadows, as it was neither used by bacteria nor accumulated in the sediment organic matter. Export of shoot material to elsewhere in the system may explain some of this limited coupling (Hemminga et al. 1991, Dauby et al. 1995, Mateo \& Romero 1997). However, a main factor was that other sources of organic matter, especially benthic production by algae, were relatively more important for organic matter cycling in the studied seagrass sediments.

Acknowledgements. J. Nieuwenhuize and Y. E. M. Maas are thanked for the stable carbon-isotope analysis of plants and sediments. We thank R. Pel and C. A. Hordijk for the use of the GC-IRMS facility at the Center for Limnology of the Netherlands Institute of Ecology (Nieuwersluis, The Netherlands). This work was partially financed by the EC-project ROBUST (ENV4-CT96-0218, ELOISE publication no. 144). Publication no. 2671 of the Netherlands Institute of Ecology, Center for Estuarine and Coastal Ecology.

\section{LITERATURE CITED}

Blaabjerg V, Mouritsen KN, Finster K (1998) Diel cycles of sulphate reduction rates in sediments of a Zostera marina bed (Denmark). Aquat Microb Ecol 15:97-102

Boschker HTS, de Brouwer JFC, Cappenberg TE (1999) The contribution of macrophyte derived organic matter to microbial biomass in salt marsh sediments: stable carbonisotope analysis of microbial biomarkers. Limnol Oceanogr 44:309-319

Caffrey JM, Kemp WM (1991) Seasonal and spatial patterns of oxygen production, respiration and root rhizome release in Potamogeton perfoliatus L. and Zostera marina L. Aquat Bot 40:109-128

Canuel EA, Freeman KH, Wakeham SG (1997) Isotopic compositions of lipid biomarker compounds in estuarine plants and surface sediments. Limnol Oceanogr 42:1570-1583

Castel J, Caumette P, Herbert R (1996) Eutrophication gradients in coastal lagoons as exemplified by the Bassin d'Arcachon and the Étang du Prévost. Hydrobiologia 329: IX-XXVIII

Coffin RB, Cifuentes LA, Pritchard PH (1997) Assimilation of oil-derived carbon and remedial nitrogen applications by intertidal food chains on a contaminated beach in Prince William Sound, Alaska. Mar Environ Res 44:27-39

Cooper LW (1989) Patterns of carbon isotopic variability in eelgrass, Zostera marina L., from Izembek Lagoon, Alaska. Aquat Bot 34:329-339

Dauby P (1989) The stable isotope ratios in benthic food webs of the Gulf of Calvi, Corsica. Cont Shelf Res 9:181-195

Dauby P, Bale AJ, Bloomer N, Canon C, Ling RD, Norro A, Robertson JE, Simon A, Théate JM, Watson AJ, Frankignoulle M (1995) Particle fluxes over a Mediterranean seagrass bed: a one year case study. Mar Ecol Prog Ser 126: 233-246 
del Giorgio PA, Cole JJ (1998) Bacterial growth efficiency in natural aquatic systems. Annu Rev Ecol Syst 29:503-541

den Hartog C (1977) Structure, function, and classification in seagrass communities. In: McRoy CP, Helfferich C (eds) Seagrass ecosystems, a scientific perspective. Dekker, New York, p 89-121

Duarte CM, Chiscano CL (1999) Seagrass biomass and productivity: a reassessment. Aquat Bot 65:159-174

Findlay RH, King GM, Watling L (1989) Efficiency of phospholipid analysis in determining microbial biomass in sediments. Appl Environ Microbiol 55:2888-2893

Fossing H, Jørgensen BB (1989) Measurement of bacterial sulfate reduction in sediments: evaluation of a single-step chromium reduction method. Biogeochemistry 8:205-222

Fourqurean JW, Moore TO, Fry B, Hollibaugh JT (1997) Spatial and temporal variation in C:N:P ratios, $\delta^{15} \mathrm{~N}$ and $\delta^{13} \mathrm{C}$ of eelgrass Zostera marina as indicators of ecosystem processes, Tomales bay, California, USA. Mar Ecol Prog Ser 157:147-157

Fry B, Sherr EB (1984) $\delta^{13} \mathrm{C}$ measurements as indicators of carbon flow in marine and freshwater ecosystems. Contrib Mar Sci 27:13-47

Gambi MC, Nowell ARM, Jumars PA (1990) Flume observations on flow dynamics in Zostera marina (eelgrass) beds. Mar Ecol Prog Ser 61:159-169

Gilmour CC, Leavitt ME, Shiaris MP (1990) Evidence against incorporation of exogenous thymidine by sulfate-reducing bacteria. Limnol Oceanogr 35:1401-1409

Guckert JB, Antworth CP, Nichols PD, White DC (1985) Phospholipid ester-linked fatty acid profiles as reproducible assays for changes in prokaryotic community structure of estuarine sediments. FEMS Microbiol Ecol 31:147-158

Hayes JM, Freeman KH, Popp BN, Hoham CH (1990) Compound-specific isotope analysis: a novel tool for reconstruction of ancient biogeochemical processes. Org Geochem 16:1115-1128

Hemminga MA, Mateo MA (1996) Stable carbon isotopes in seagrasses: variability in ratios and use in ecological studies. Mar Ecol Prog Ser 140:285-298

Hemminga MA, Harrison PG, van Lent F (1991) The balance of nutrient losses and gains in seagrass meadows. Mar Ecol Prog Ser 71:85-96

Hemminga MA, Slim FJ, Kazungu J, Ganssen GM, Nieuwenhuize J, Kruyt NM (1994) Carbon outwelling from a mangrove forest with adjacent seagrass beds and coral reefs (Gazi Bay, Kenya). Mar Ecol Prog Ser 106:291-301

Holmer M, Nielsen SL (1997) Sediment sulfur dynamics related to biomass density patterns in Zostera marina (eelgrass) beds. Mar Ecol Prog Ser 146:163-171

Isaksen MF, Finster K (1996) Sulphate reduction in the root zone of the seagrass Zostera noltii on the intertidal flats of a coastal lagoon (Arcachon, France). Mar Ecol Prog Ser 137:187-194

Jørgensen BB (1978) A comparison of methods for quantification of bacterial sulfate reduction in coastal marine sediments: I. Measurements with radiotracer techniques. Geomicrobiol J 1:11-27

López NI, Duarte CM, Vallespinós F, Romero J, Alcoverro T (1995) Bacterial activity in NW Mediterranean seagrass (Posidonia oceanica) sediments. J Exp Mar Biol Ecol 187: 39-49

Mann KH (1988) Production and use of detritus in various freshwater, estuarine, and coastal marine ecosystems. Limnol Oceanogr 33:910-930

Mateo MA, Romero J (1997) Detritus dynamics in the seagrass Posidonia oceanica: elements for an ecosystem carbon and nutrient budget. Mar Ecol Prog Ser 151:43-53
McMillan C, Parker PL, Fry B (1980) ${ }^{13} \mathrm{C} /{ }^{12} \mathrm{C}$ ratios in seagrasses. Aquat Bot 9:237-249

Middelburg JJ, Barranguet C, Boschker HTS, Herman PMJ, Moens T, Heip CHR (2000) The fate of intertidal microphytobenthos carbon: an in situ ${ }^{13} \mathrm{C}$ labeling study. Limnol Oceanogr (in press)

Miyajima T, Koike I, Yamano H, Iizumi H (1998) Accumulation and transport of seagrass-derived organic matter in reef flat sediment of Green Island, Great Barrier Reef. Mar Ecol Prog Ser 175:251-259

Moncreiff CA, Sullivan MJ, Daehnick AE (1992) Primary production dynamics in seagrass beds of Mississippi sound - the contributions of seagrass, epiphytic algae, sand microflora, and phytoplankton. Mar Ecol Prog Ser 87:161-171

Moriarty DJW, Pollard PC (1982) Diel variation of bacterial productivity in seagrass (Zostera capricorni) beds measured by rate of thymidine incorporation in DNA. Mar Biol 72:165-173

Moriarty DJW, Iverson RL, Pollard PC (1986) Exudation of organic carbon by the seagrass Halodule wrightii Aschers. and its effect on bacterial growth in the sediment. J Exp Mar Biol Ecol 96:115-126

Murray L, Wetzel RL (1987) Oxygen production and consumption associated with the major autotrophic components in two temperate seagrass communities. Mar Ecol Prog Ser 38:231-239

Nieuwenhuize J, Maas YEM, Middelburg JJ (1994) Rapid analysis of organic carbon and nitrogen particulate materials. Mar Chem 44:217-224

Oremland RS, Taylor BF (1977) Diurnal fluctuations of $\mathrm{O}_{2}, \mathrm{~N}_{2}$, and $\mathrm{CH}_{4}$ in the rhizosphere of Thalassia testudinum. Limnol Oceanogr 22:566-570

Parkes RJ (1987) Analysis of microbial communities within sediments using biomarkers. In: Hetcher M, Gray TRG, Jones JG (eds) Ecology of microbial communities. Cambridge University Press, Cambridge, p 147-177

Pedersen O, Borum J, Duarte CM, Fortes MD (1998) Oxygen dynamics in the rhizosphere of Cymodocea rotundata. Mar Ecol Prog Ser 169:283-288

Pollard PC, Moriarty DJW (1991) Organic-carbon decomposition, primary and bacterial productivity, and sulphate reduction, in tropical seagrass beds of the Gulf of Carpentaria, Australia. Mar Ecol Prog Ser 69:149-159

Ratledge C, Wilkinson SG (1989) Microbial lipids. Academic Press, London

Richard P, Riera P, Galois R (1997) Temporal variations in the chemical and carbon isotope compositions of marine and terrestrial organic inputs in the bay of Marennes-Oléron, France. J Coast Res 13:879-889

Rieley G (1994) Derivatisation of organic compounds prior to gas chromatographic-combustion-isotope ratio mass spectrometric analysis: identification of isotope fractionation processes. Analyst Lond 119:915-919

Salomons W, Mook WG (1981) Field observations of the isotopic composition of particulate organic carbon in the southern North Sea and adjacent estuaries. Mar Geol 41: $11-40$

Simenstad CA, Wissmar RC (1985) $\delta^{13} \mathrm{C}$ evidence of the origins and fates of organic carbon in estuarine and nearshore food webs. Mar Ecol Prog Ser 22:141-152

Smith RD, Dennison WC, Alberte RS (1984) Role of seagrass photosynthesis in root aerobic processes. Plant Physiol 74:1055-1058

Swinnen J, van Veen JA, Merckx R (1994) Losses of ${ }^{14} \mathrm{C}$ from roots of pulse-labelled wheat and barley during washing from soil. Plant Soil 166:93-99 
Thayer GW, Parker PL, LaCroix MW, Fry B (1978) The stable isotope ratio of some components of an eelgrass, Zostera marina, bed. Oecologia 35:1-12

Tunlid A, White DC (1992) Biochemical analysis of biomass, community structure, nutritional status, and metabolic activity of microbial communities in soil. Soil Biochem 7: 229-262

van Lent F, Verschuure JM (1994) Intraspecific variability of Zostera marina L. (eelgrass) in the estuaries and lagoons of the southwestern Netherlands. 1. Population dynamics. Aquat Bot 48:31-58

Voss M, Struck U (1997) Stable nitrogen and carbon isotopes as indicator of eutrophication of the Oder River (Baltic sea). Mar Chem 59:35-49

Editorial responsibility: Otto Kinne (Editor),

Oldendorf/Luhe, Germany
Wellsbury P, Parkes RJ, Herbert RA (1994) Bacterial [methyl$\left.{ }^{3} \mathrm{H}\right]$-thymidine incorporation in substrate-amended estuarine sediment slurries. FEMS Microbiol Ecol 15:237-248

Welsh DT, Bourguès S, de Wit R, Auby I (1997) Effect of plant photosynthesis, carbon sources and ammonium availability on nitrogen fixation rates in the rhizosphere of Zostera noltii. Aquat Microb Ecol 12:285-290

Wetzel RG, Penhale PA (1979) Transport of carbon and excretion of dissolved organic carbon by leaves and roots/rhizomes in seagrasses and their epiphytes. Aquat Bot 6: $149-158$

Worcester SE (1995) Effects of eelgrass beds on advection and turbulent mixing in low current and low shoot density environments. Mar Ecol Prog Ser 126:223-232

Submitted: August 8, 1999; Accepted: April 6, 2000

Proofs received from author(s): August 21, 2000 